EPRA International Journal of Economic and Business Review-Peer Reviewed Journal Volume - 10, Issue - 2, February 2022 | e-ISSN: 2347 - 9671| p- ISSN: 2349 - 0187

\title{
A STATE-WISE ANALYSIS ON GOVERNMENT SPONSORED HEALTH INSURANCE SCHEMES IN INDIA
}

\author{
Dr.V.Pugazhenthi \\ Controller of Examinations, Associate Professor and HoD of Commerce, \\ Rajah Serfoji Government College, Thanjavur-5
}

\begin{abstract}
DOI No: 10.36713/epra9553 particularly the hilly states and Union Territories (UTs). Schemes, AB-PMJAY.

JEL Classifications: I13, 118

Government Sponsored Health Insurance Schemes are the health insurance schemes subsidized fully or partly by the Union or State Government or both, for the welfare of its people. These schemes help people avail of the benefits of medical insurance at a minimal cost. Though it is claimed as cashless, it ends up at least less-cash treatment, practically. In this paper the Government Sponsored Health Insurance Schemes prevailing presently in India and their state wise performance in the year 2019-20, from the view of the insurance Industry is analysed.
\end{abstract}

Article DOI: $\underline{\text { https://doi.org/10.36713/epra9553 }}$

Government Sponsored Health Insurance Schemes (GSHISs) are those health insurance schemes which are subsidized fully or partly by the Union or State Government or both in India. This may be for the welfare of its poor people or for a section of people like employees, pensioners journalists, etc. In this paper the GSHISs prevailing presently in India and their state wise performance in the year 2019-20, from the view of the insurance Industry is examined. How many persons are covered under GSHISs, amount of premium paid to the insurer under GSHISs, amount of claims paid by the insurer under GSHISs and number of claim paid by the insurer under GSHISs are the four factors considered for comparison. Abstract figures for all these factors and their comparisons against the other Group Health Insurance Policies and Total number of Health Policies are analyzed. It shows that the southern states like Tamil Nadu, Kerala, Goa are performing better than other states

KEYWORDS: Health Insurance premium, Health Insurance Claims, Government Sponsored Health Insurance

\section{CGHISS IN INDIA}

Ayushman Bharat PM-JAY is the largest health assurance scheme in the world which aims at providing a health cover of Rs. 5 lakhs per family per year for secondary and tertiary care hospitalization to over 10.74 crores poor and vulnerable families (approximately 50 crore beneficiaries) that form the bottom $40 \%$ of the Indian population. The households included are based on the deprivation and occupational criteria of Socio-Economic Caste Census 2011 (SECC 2011) for rural and urban areas respectively. PM-JAY 
was earlier known as the National Health Protection Scheme (NHPS) before being rechristened. It subsumed the then existing Rashtriya Swasthya Bima Yojana (RSBY) which had been launched in 2008. The coverage mentioned under PM-JAY, therefore, also includes families that were covered in RSBY but are not present in the SECC 2011 database. PM-JAY is fully funded by the Government and cost of implementation is shared between the Central and State Governments. Apart from the AB-PMJAY, there are a few other GSHISs which are already converged with or in the process of convergence with ABPMJAY. It includes

-Rashtriya Swasthya Bima Yojana for Labourers by the Ministry of Labour and for workers in the unorganised sector and their families but only up to 5 people, which was subsumed by AB-PMJAY.

-Pradhan Mantri Suraksha Bima Yojana providing accident insurance cover to the people of India. People in the age group of 18 years to 70 years who have an account in a bank for an annual cover of Rs 2 lakh for total disability and death cover and Rs 1 lakh for partial disability;

-Aam Aadmi Bima Yojana (AABY), for the landless citizens who are tenants living both in urban and rural wherein upon a natural death, the family is compensated at 30000 rupees and upon death caused by a permanent disability, the family is compensated at 75,000 rupees;

-Central Government Health Scheme (CGHS) providing comprehensive health care facilities for central government officials and pensioners;

-Employment State Insurance Scheme applicable to all permanent factories employing more than ten employees. Recently, the scheme has been extended to various businesses including shops, restaurants, road and motor transports and newspaper entities that employ more than 20 people;

-Janshree Bima Yojana, for individuals in the 45 occupational groups who are within the age group of 18-59 years like Women SHG Groups and Shiksha Sahyog Yojana;

-Universal Health Insurance Scheme (UHIS), for the families who live below the poverty covering the medical expenses up to 30,000 rupees;

-West Bengal Health Scheme, for employees and pensioners as family floater up to a sum insured of Rs 1 lakh;
-Yeshasvini Health Insurance Scheme of Karnataka State Government for peasants and farmers and who are associated with a co-operative society;

- Mahatma Jyotiba Phule Jan Arogya Yojana of Government of Maharashtra for below the poverty line and was targeted at the farmers in Maharashtra offering a family health cover of up to Rs 1.5 lakh for specified illnesses;

-Mukhyamantri Amrutam Yojana of the Gujarat government in the year 2012 for the benefit of the poor offering a family floater health insurance policy that provides coverage up to Rs 3 lakh per family;

-Karunya Health Scheme of the Kerala Government to provide health cover for listed chronic illnesses for the poor;

- Awaz Health Insurance Scheme of Kerala government in 2017, covering the inter-state labourers in Kerala, who are without medical coverage up to Rs.15000 and death benefit upto Rs.2 lakh;

-Telangana State Government Employees and Journalists Health Scheme for its employees and pensioners to avail of cashless treatment in the hospitals registered;

- Four health welfare schemes launched under Dr YSR Aarogyasri Health Care Trust by the Andhra Pradesh Government namely Dr YSR Aarogyasri scheme for the welfare of the poor, Arogya Raksha scheme is for Above the Poverty Line, Working Journalist Health Scheme that provides cashless treatment cover for specified procedures, Employee Health Scheme provides health cover to the state government employees.

-Bhamashah Swasthya Bima Yojana to offer healthcare coverage to rural residents of Rajasthan.

--Chief Minister's Comprehensive Insurance Scheme, a family floater health policy for poor earning less than Rs.120000 per annum that was designed to provide a thousand plus medical procedures up to Rs 5 lakh;

-New Health Schemes of Tamil Nadu for its Employees and Pensioners, which are partly subsidized by the State and mainly contributed by State Government/ Semi Government employees and Pensioners.

Following is the list of GSHISs which were merged with AB-PMJAY but controlled by various State Health Agencies and the Insurance Company offering the insurance services. 
Table No.1: List of the AB-PMJAY-annexed Insurer-linked- GSHISs in India

\begin{tabular}{|c|c|c|c|}
\hline $\begin{array}{l}\text { Name of the } \\
\text { State/UT }\end{array}$ & Name of Scheme in the State/UT & $\begin{array}{l}\text { Name of Scheme in the } \\
\text { State/UT }\end{array}$ & Name of the Insurer \\
\hline $\begin{array}{l}\text { Dadra and } \\
\text { Nagar Haveli } \\
\text { and Daman } \\
\text { and Diu }\end{array}$ & $\begin{array}{l}\text { Ayushman Bharat } \\
\text { Pradhan Mantri Jan Arogya Yojana } \\
\text { (PM-JAY) }\end{array}$ & $\begin{array}{l}\text { State Health Agency, Dadra } \\
\text { and Nagar Haveli and Daman } \\
\text { and Diu }\end{array}$ & $\begin{array}{l}\text { The Oriental } \\
\text { Insurance Company } \\
\text { Ltd. }\end{array}$ \\
\hline \multirow[t]{2}{*}{ Gujarat } & $\begin{array}{l}\text { Ayushman Bharat } \\
\text { Pradhan Mantri Jan Arogya Yojana } \\
\text { (PM-JAY); }\end{array}$ & \multirow[t]{2}{*}{$\begin{array}{l}\text { Gujarat State Health } \\
\text { Protection Society }\end{array}$} & \multirow[t]{2}{*}{$\begin{array}{l}\text { The Oriental } \\
\text { Insurance Company } \\
\text { Ltd. }\end{array}$} \\
\hline & $\begin{array}{l}\text { Mukhyamantri Amrutam \& } \\
\text { Mukhyamantri Vatsalya }\end{array}$ & & \\
\hline $\begin{array}{l}\text { Jammu And } \\
\text { Kashmir }\end{array}$ & $\begin{array}{l}\text { Ayushman Bharat } \\
\text { Pradhan Mantri Jan Arogya Yojana } \\
\text { (PM-JAY) SEHAT }\end{array}$ & $\begin{array}{l}\text { State Health Agency Jammu } \\
\text { and Kashmir }\end{array}$ & $\begin{array}{l}\text { Bajaj Allianz General } \\
\text { Insurance Company } \\
\text { Limited }\end{array}$ \\
\hline Jharkhand & $\begin{array}{l}\text { Ayushman Bharat- } \\
\text { Mukhyamantri Jan Arogya Yojana (AB- } \\
\text { MJAY) }\end{array}$ & $\begin{array}{l}\text { Jharkhand State Arogya } \\
\text { Society }\end{array}$ & $\begin{array}{l}\text { National Insurance } \\
\text { Company }\end{array}$ \\
\hline Ladakh & $\begin{array}{l}\text { Ayushman Bharat } \\
\text { Pradhan Mantri Jan Arogya Yojana } \\
\text { (PM-JAY) }\end{array}$ & State Health Society (NHM) & $\begin{array}{l}\text { Bajaj Allianz General } \\
\text { Insurance Company } \\
\text { Limited }\end{array}$ \\
\hline \multirow[t]{2}{*}{ Maharashtra } & $\begin{array}{l}\text { Ayushman Bharat } \\
\text { Pradhan Mantri Jan Arogya Yojana } \\
\text { (PM-JAY) }\end{array}$ & \multirow[t]{2}{*}{$\begin{array}{l}\text { State Health Assurance } \\
\text { Agency }\end{array}$} & \multirow[t]{2}{*}{$\begin{array}{l}\text { United India } \\
\text { Insurance Company } \\
\text { Limited }\end{array}$} \\
\hline & $\begin{array}{l}\text { Mahatma Jyotiba Phule Jan Arogya } \\
\text { Yojana (MPJAY) }\end{array}$ & & \\
\hline \multirow[t]{2}{*}{ Meghalaya } & $\begin{array}{l}\text { Megha Health Insurance Scheme } \\
\text { (MHIS) }\end{array}$ & \multirow[t]{2}{*}{$\begin{array}{l}\text { State Nodal Agency } \\
\text { Meghalaya }\end{array}$} & \multirow{2}{*}{$\begin{array}{l}\text { Reliance General } \\
\text { Insurance Company } \\
\text { Ltd. }\end{array}$} \\
\hline & $\begin{array}{l}\text { Pradhan Mantri Jan Arogya Yojana } \\
\text { (PMJAY) }\end{array}$ & & \\
\hline Nagaland & $\begin{array}{l}\text { Ayushman Bharat } \\
\text { Pradhan Mantri Jan Arogya Yojana } \\
\text { (PM-JAY) }\end{array}$ & $\begin{array}{l}\text { SHA (AB-PMJAY), } \\
\text { Nagaland }\end{array}$ & $\begin{array}{l}\text { The Oriental } \\
\text { Insurance Company } \\
\text { Ltd. }\end{array}$ \\
\hline Punjab & $\begin{array}{l}\text { Ayushman Bharat Sarbat Sehat Bima } \\
\text { Yojana }\end{array}$ & State Health Agency unjab & IFFKO Tokyo \\
\hline \multirow[t]{2}{*}{ Rajasthan } & Ayushman Bharat-Mahatma Gandhi & \multirow{2}{*}{$\begin{array}{l}\text { Rajasthan State Health } \\
\text { Assurance Agency }\end{array}$} & \multirow[t]{2}{*}{ New India Assurance } \\
\hline & Rajasthan Swasthya Bima Yojana & & \\
\hline Tamil Nadu & $\begin{array}{l}\text { Pradhan Mantri Jan Arogya Yojana- } \\
\text { Chief Minister's Comprehensive Health } \\
\text { Insurance Scheme (PMJAY-CMCHIS) }\end{array}$ & $\begin{array}{l}\text { Tamil Nadu Health System } \\
\text { Project (TNHSP) }\end{array}$ & $\begin{array}{l}\text { United India } \\
\text { Insurance Ltd. }\end{array}$ \\
\hline
\end{tabular}

Source: Extracted from the data available from https://pmjay.gov.in/

\section{GSHISS TREND}

Comparing the GSHISs data available from the year 2014-15 to 2019-20, it is evident that in the Country, more than $72 \%$ of the Health Insured Indian population got insured only by the GSHISs all through the six years. Though in 2015-16, registered a maximum coverage of $76.58 \%$ it seems to surpass even the $80 \%$ mark in the present and coming years, on account of speedy and structured penetration of $\mathrm{AB}$ -
PMJAY. Tamil Nadu along with Maharashtra has been performing outstandingly well in giving cover under the GSHISs. Tamil Nadu which witnessed a boom in GSHISs coverage with $79 \%$ being insured in GSHISs in the year 2017-18. From then on, due to the increased awareness and the perception of increased demand of health cover private insurance preference made the GSHISs coverage down to $71.49 \%$ in 2019-20. 
Table No.2: GSHISs Coverage Trend and Claims Trend

\begin{tabular}{|c|c|c|c|c|c|c|}
\hline Year & $\begin{array}{c}2014 \\
-15\end{array}$ & $\begin{array}{c}2015 \\
-16\end{array}$ & $\begin{array}{c}2016 \\
-17\end{array}$ & $\begin{array}{c}2017 \\
-18\end{array}$ & $\begin{array}{c}2018 \\
-19\end{array}$ & $\begin{array}{c}2019 \\
-20\end{array}$ \\
\hline $\begin{array}{l}\text { Proportion of Persons Covered by Health Insurance (Govt } \\
\text { Sponsored to Total) in Tamil Nadu }\end{array}$ & $\begin{array}{c}75.34 \\
\%\end{array}$ & $\begin{array}{c}76.76 \\
\%\end{array}$ & $\begin{array}{c}78.01 \\
\%\end{array}$ & $\begin{array}{c}79.14 \\
\%\end{array}$ & $\begin{array}{c}71.70 \\
\%\end{array}$ & $\begin{array}{c}71.49 \\
\%\end{array}$ \\
\hline $\begin{array}{l}\text { Proportion of Persons Covered by Health Insurance (Govt } \\
\text { Sponsored to Total) in India }\end{array}$ & $\begin{array}{c}74.42 \\
\%\end{array}$ & $\begin{array}{c}76.58 \\
\%\end{array}$ & $\begin{array}{c}76.13 \\
\%\end{array}$ & $\begin{array}{c}74.54 \\
\%\end{array}$ & $\begin{array}{c}75.65 \\
\%\end{array}$ & $\begin{array}{c}72.58 \\
\%\end{array}$ \\
\hline $\begin{array}{l}\text { Proportion of Health Insurance Claim Settled (Govt Sponsored to } \\
\text { Total) in Tamil Nadu }\end{array}$ & $\begin{array}{c}22.20 \\
\%\end{array}$ & $\begin{array}{c}16.83 \\
\%\end{array}$ & $\begin{array}{c}15.37 \\
\%\end{array}$ & $\begin{array}{c}16.81 \\
\%\end{array}$ & $\begin{array}{c}11.19 \\
\%\end{array}$ & $\begin{array}{c}13.40 \\
\%\end{array}$ \\
\hline $\begin{array}{l}\text { Proportion of Health Insurance Claim Settled (Govt Sponsored to } \\
\text { Total) in India }\end{array}$ & $\begin{array}{c}11.66 \\
\%\end{array}$ & $\begin{array}{c}12.70 \\
\%\end{array}$ & $\begin{array}{c}9.81 \\
\%\end{array}$ & $\begin{array}{c}12.82 \\
\%\end{array}$ & $\begin{array}{c}11.87 \\
\%\end{array}$ & $\begin{array}{c}12.38 \\
\%\end{array}$ \\
\hline
\end{tabular}

Source: Extracted from various IRDA Annal Reports

In the same period, around $11 \%$ to $12 \%$ of the total health insurance claims settled were for the claims covered under GSHISs. A maximum of $12.82 \%$ claims settled in health insurance industry was observed in the GSHISs alone in the country in the year 2017-18 and the of GSHISs claims the previous year 2016-17. Due to a high penetration of GSHISs like modified CMCHIS in Tamil Nadu, more than a fifth of the Health Insurance claims were for GSHISs in 2014-15. Though it is in a falling trend, the GSHIS claims to total health claims ratio of Tamil Nadu (i.e., 13.40\%) still is better than the Indian average (i.e., 12.38\%), as observed in the year 2019-10.

Of all the 11394 general and stand-alone health insurer offices situated in India, Maharashtra has 1401 and Tamil Nadu has 1209.These are the only two states in which thousand plus offices serve the Health insured in the Country. In other words, these two states the Health Insurance penetration is more and in addition to the GSHISs, the self-subscription to health insurance also is at its high.

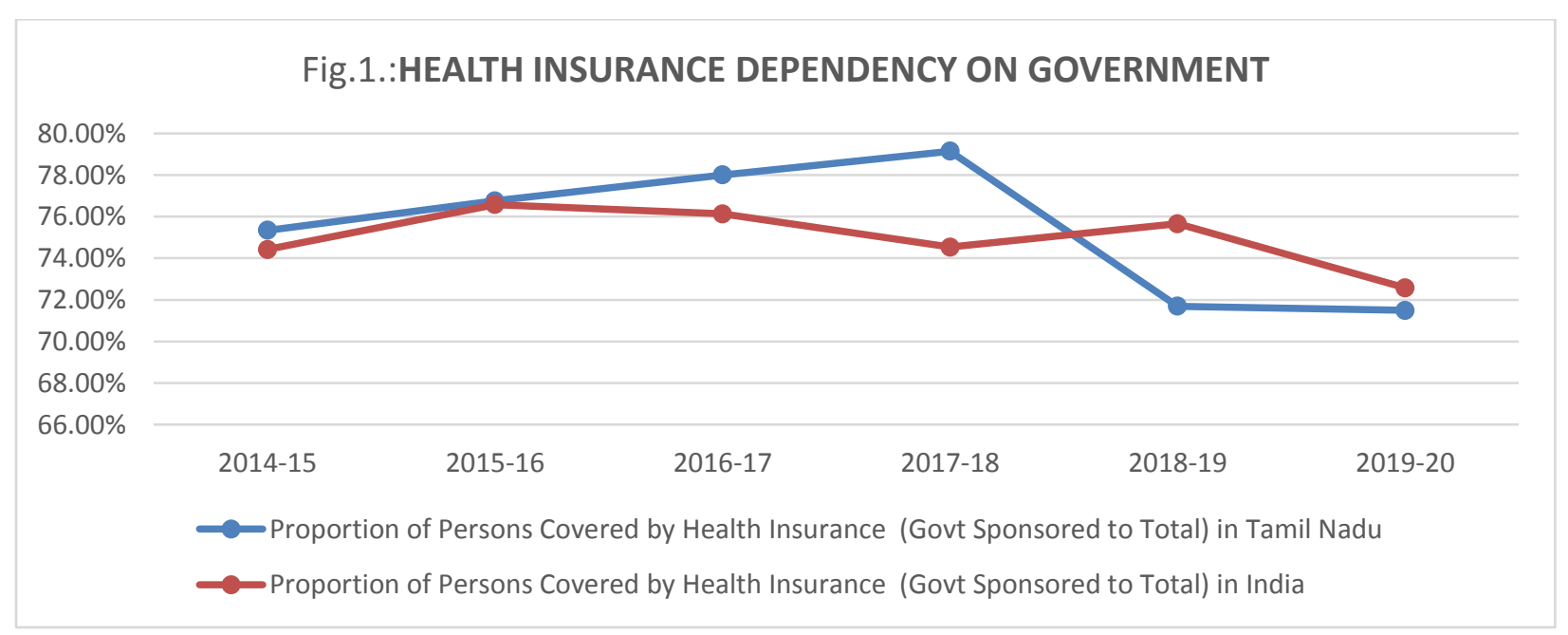

Source: Based on the IRDA Annal Report 2019-20 


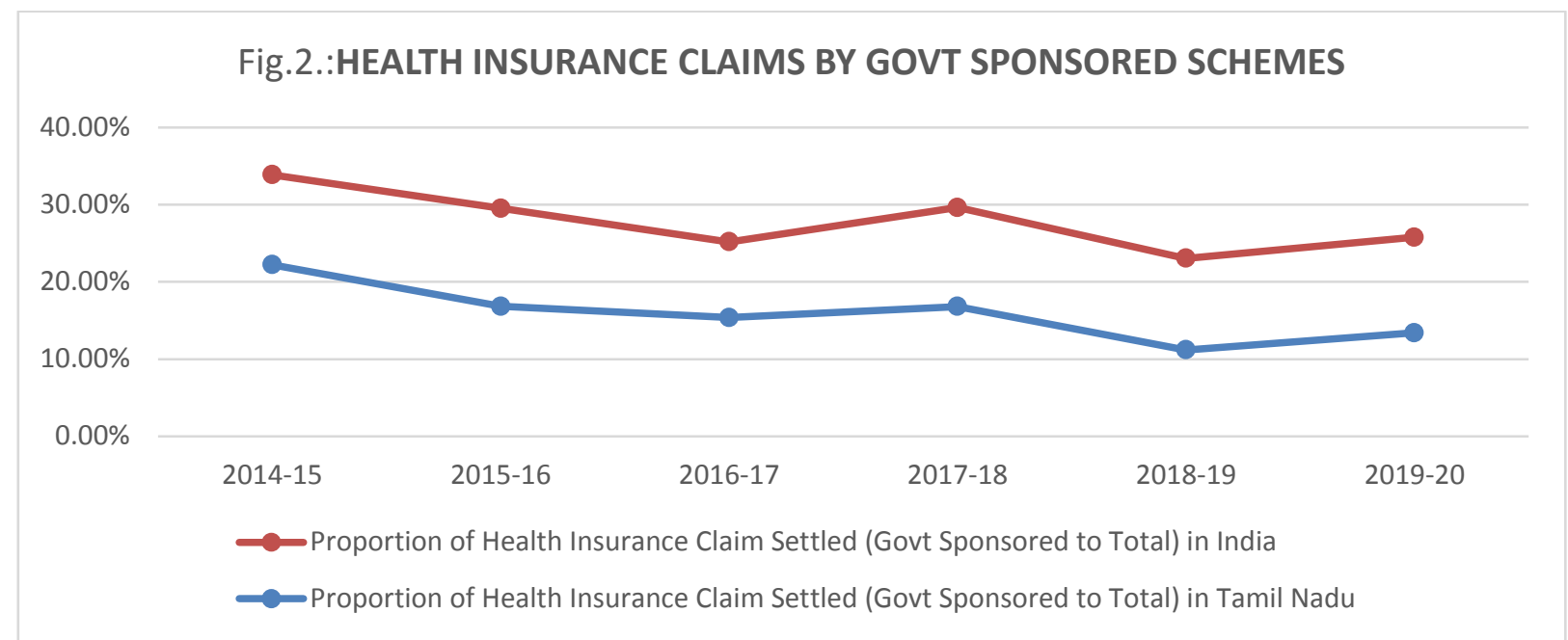

Source: Based on the IRDA Annal Report 2019-20

\section{GSHISS IN 2019-20:}

In terms of amounts of claims paid, out of the total claims of Rs. 495371 Lakhs, Maharashtra stands first with Rs. 136885 Lakhs which is followed by Rajasthan. Tamil Nadu is in the third position as far as the claims paid under Government Sponsored Health Insurance Schemes in the year 2019-20 with Rs. 55692 Lakhs. Chhattisgarh, Kerala, West Bengal, Jharkhand, Punjab and Gujarat are the six other states surpassing Rs. 10000 Lakhs mark of claims under GSHISs.

In terms of number of persons covered under GSHISs, out of the 36 plus crore people covered, Maharashtra stands first with 117millions coverage which is followed by West Bengal. Tamil Nadu is in the third position as far as the number of persons covered under Government Sponsored Health Insurance Schemes in the year 2019-20 with 39.83 million insured. Rajasthan, Jharkhand, Gujarat, Orissa, Punjab, Karnataka and Chhattisgarh are the seven other states surpassing 10 million mark of health insured under GSHISs.

In terms of Gross Direct Premium collected under GSHISs, out of Rs. 492062 Lakhs, Maharashtra stands first with Rs. 113936 Lakhs which is followed by Kerala and Rajasthan. Tamil Nadu is in the fourth position as far as the Gross Direct Premium collected under Government Sponsored Health Insurance Schemes in the year 2019-20 with Rs. 61513 Lakhs. West Bengal, Chhattisgarh, Jharkhand, Punjab and Gujarat are the other states surpassing Rs.10000 Lakhs mark of Gross Direct Premium collected under GSHISs.

In terms of number of claims paid under GSHISs, out of the 5628223 number of claims, the state of Rajasthan stands first honoring 1.45 million number of claims which is followed by Kerala. Tamil Nadu is in the third position as far as the number of claims paid under Government Sponsored Health Insurance Schemes in the year 2019-20 with 7.76 lakhs claims honoured. Maharashtra though seems premier in all other scales like premium paid, Claims given and number of insured people under GSHISs, is found only in the fourth place with 6.87 lakhs number of claims. Chhattisgarh, West Bengal, Jharkhand and Punjab are the four other states surpassing one lakh mark of number of claims under GSHISs. 
GSHIS IN 2019-20

Table No.3: State-wise Performance of GSHISs in 2019-20

(No of policies and no of claims in actuals) (No. of persons in '000)

(Premium and Amount of claims in ₹ Lakh)

\begin{tabular}{|c|c|c|c|c|c|}
\hline States & $\begin{array}{l}\text { No. of } \\
\text { policies } \\
\text { Issued }\end{array}$ & $\begin{array}{l}\text { No. of persons } \\
\text { Covered }\end{array}$ & $\begin{array}{l}\text { Gross Direct } \\
\text { Premium }\end{array}$ & $\begin{array}{l}\text { No. of claims } \\
\text { paid }\end{array}$ & $\begin{array}{c}\text { Amount of } \\
\text { Claims Paid }\end{array}$ \\
\hline Andhra Pradesh & 0 & 0 & 0 & 0 & 0 \\
\hline Arunachal Pradesh & 0 & 0 & 0 & 0 & 0 \\
\hline Assam & 0 & 0 & 515 & 15708 & 762 \\
\hline Bihar & 7 & 5659 & -560 & 0 & 0 \\
\hline Chhattisgarh & 2 & 12200 & 42979 & 596089 & 47786 \\
\hline Goa & 0 & 0 & 0 & 129 & 71 \\
\hline Gujarat & 11 & 21552 & 8070 & 84031 & 10396 \\
\hline Haryana & 0 & 0 & 0 & 0 & 0 \\
\hline Himachal Pradesh & 12 & 1549 & 0 & 14851 & 748 \\
\hline Jharkhand & 1 & 26284 & 39632 & 364659 & 34911 \\
\hline Karnataka & 17 & 13592 & 4 & 36 & 12 \\
\hline Kerala & 1 & 7191 & 69353 & 889197 & 47699 \\
\hline Madhya Pradesh & 0 & 0 & 0 & 0 & 0 \\
\hline Maharashtra & 6 & 117293 & 113936 & 687399 & 136885 \\
\hline Manipur & 6 & 213 & 0 & 110 & 7 \\
\hline Meghalaya & 22 & 744 & 0 & 8430 & 548 \\
\hline Mizoram & 0 & 0 & 0 & 1744 & 279 \\
\hline Nagaland & 2 & 943 & 1583 & 8936 & 1050 \\
\hline Orissa & 33 & 20875 & 4531 & 71895 & 4562 \\
\hline Punjab & 3 & 15432 & 24700 & 173276 & 21737 \\
\hline Rajasthan & 1 & 32866 & 62624 & 1452796 & 91203 \\
\hline Sikkim & 0 & 0 & 0 & 0 & 0 \\
\hline Tamil Nadu & 6 & 39829 & 61513 & 775919 & 55692 \\
\hline Telangana & 0 & 0 & 0 & 0 & 0 \\
\hline Tripura & 0 & 0 & 0 & 0 & 0 \\
\hline Uttar Pradesh & 0 & 0 & 0 & 0 & 42 \\
\hline Uttarakhand & 0 & 0 & 0 & 0 & 0 \\
\hline West Bengal & 105 & 44911 & 60783 & 463187 & 39405 \\
\hline Andaman \& Nicobar Is. & 0 & 0 & 0 & 0 & 0 \\
\hline Chandigarh & 0 & 0 & 110 & 7 & 9 \\
\hline $\begin{array}{l}\text { Dadra \& Nagar Haveli and } \\
\text { Daman \& Diu }\end{array}$ & 7 & 570 & 2088 & 18567 & 1477 \\
\hline Delhi & 0 & 0 & 0 & 0 & 0 \\
\hline Jammu \& Kashmir & 0 & 0 & 0 & 3 & 2 \\
\hline Lakshadweep & 0 & 0 & 0 & 0 & 0 \\
\hline Puducherry & 1 & 269 & 201 & 1254 & 89 \\
\hline Total & 243 & 361971 & 492062 & 5628223 & 495371 \\
\hline
\end{tabular}

Source: Author's Calculations based on the IRDA Annal Report 2019-20 


\section{COMPARISON WITH OTHER GROUP HEALTH POLICIES IN 2019-20}

GSHIS is also yet another form of Group Insurance scheme but the premium is paid by the Government. So, a comparison between these two GSHISs vs other Group Policies is made. It reveals that in the state of Nagaland, only GSHIS- form of Group Health policies are popular as health-insured under GSHISs are 254.76 times more than the health-insured under Normal Group policies in the year 2019-20. In total, in the country 3.87 times of the health-insured under Normal Group policies are health insured under GSHISs. Meghalaya, Jharkhand, Dadra \& Nagar Haveli and Daman \& Diu, Rajasthan, Himachal Pradesh, Orissa, Punjab, Chhattisgarh, West Bengal, Manipur, Gujarat, Puducherry, Bihar, are the other states /Union Territories which are above this national average. In the state of Tamil Nadu around health insured persons in GSHISs are 3.8 times more than the general Group Health Insured ones in the year 2019-20.

Similarly, only 0.19 times of Gross Direct Premium of Group Health Insurance policies of nonlife insurers in the year 2019-20 was collected as Gross Direct Premium of GSHISs in India as a whole. As a maximum, Nagaland had nearly 21 times of General Group Health Insurance policies of non-life insurers as that of GSHISs. Jharkhand, Rajasthan, Dadra \& Nagar Haveli and Daman \& Diu, Chhattisgarh, Punjab, Kerala, West Bengal and Orissa $\mathrm{Re}$ the other states/UTs in decreasing order who are having the national average (i.e., 0.19 times) in the Premium collected in GSHISs comparing other Group Health policies. Tamil Nadu, one of the fore runner in GSHISs is also better in subscribing other forms of Group
Health Insurance also as it had 0.18 times of the Group Health Premium as GSHISs Premium in 2019-20.

Comparing the number of claims paid under GSHISs to the number of claims paid under other Group Health Policies, in the year 2019-20, around 0.71 times of the number of health insurance claims under the General Group Health Claims are paid by the insurance industry as GSHISs claims. Due to the conservative health claim packages under GSHISs, 0.22 times of the amount of claims are paid by the insurance industry as GSHISs claims, comparing Group Health Claims in the year 2019-20 in India. As a leading state, in Nagaland, 894 times of the total number of the group health insurance claims paid (334 times of the amount of claims) are made under the GSHISs only, which is no near to the national average. Another North East State Mizoram is in the second place with around 125 times of the number of group health insurance claims (67.82 times in amount of total amount of health claims) in GSHISs.

Meghalaya, Rajasthan, Dadra \& Nagar Haveli and Daman \& Diu, Jharkhand, Himachal Pradesh, Kerala, Chhattisgarh, Punjab, West Bengal, Assam and Orissa are the other states /Union Territories which are also above the national average of 0.71 times of Group Claim Numbers as GSHISs claims in decreasing order. In terms of Amount of Claims also, all these 11 states along with above mentioned Nagaland and Mizoram had GSHISs claims higher than the national average of 0.22 times of Group Health Claim Amount. In the state of Tamil Nadu 1.11 times of the Group Claim Numbers as GSHISs claims and 0.2 times of Group Claim Amount as GSHISs claims in the year 2019-20.

Table No.4: GSHISs vs Group Health Insurance Schemes and Total Health Insurance Schemes

\begin{tabular}{|c|c|c|c|c|c|c|c|c|c|c|}
\hline \multirow[t]{2}{*}{ States } & \multicolumn{5}{|c|}{$\begin{array}{l}\text { Govt. Sponsored Schemes to other group policies } \\
\text { (in times) }\end{array}$} & \multicolumn{5}{|c|}{ Govt. Sponsored Schemes to total Health policies } \\
\hline & $\begin{array}{c}\text { No.of } \\
\text { policies } \\
\text { Issued }\end{array}$ & $\begin{array}{c}\text { No. of } \\
\text { persons } \\
\text { Covered }\end{array}$ & $\begin{array}{c}\text { Gross } \\
\text { Direct } \\
\text { Premium }\end{array}$ & $\begin{array}{c}\text { No. of } \\
\text { claims } \\
\text { paid }\end{array}$ & $\begin{array}{c}\text { Amount } \\
\text { of } \\
\text { Claims } \\
\text { Paid }\end{array}$ & $\begin{array}{c}\text { No.of } \\
\text { policies } \\
\text { Issued }\end{array}$ & $\begin{array}{c}\text { No. of } \\
\text { persons } \\
\text { Covered }\end{array}$ & $\begin{array}{c}\text { Gross } \\
\text { Direct } \\
\text { Premium }\end{array}$ & $\begin{array}{c}\text { No. of } \\
\text { claims } \\
\text { paid }\end{array}$ & $\begin{array}{c}\begin{array}{c}\text { Amount } \\
\text { of } \\
\text { Claims }\end{array} \\
\text { Paid }\end{array}$ \\
\hline Andhra Pradesh & 0.00 & 0.00 & 0.00 & 0.00 & 0.00 & $0.00 \%$ & $0.00 \%$ & $0.00 \%$ & $0.00 \%$ & $0.00 \%$ \\
\hline Arunachal Pradesh & 0.00 & 0.00 & 0.00 & 0.00 & 0.00 & $0.00 \%$ & $0.00 \%$ & $0.00 \%$ & $0.00 \%$ & $0.00 \%$ \\
\hline Assam & 0.00 & 0.00 & 0.09 & 1.86 & 0.38 & $0.00 \%$ & $0.00 \%$ & $2.65 \%$ & $47.81 \%$ & $10.80 \%$ \\
\hline Bihar & 0.00 & 4.59 & -0.06 & 0.00 & 0.00 & $0.01 \%$ & $78.18 \%$ & $-2.40 \%$ & $0.00 \%$ & $0.00 \%$ \\
\hline Chhattisgarh & 0.00 & 13.95 & 1.67 & 4.15 & 12.91 & $0.00 \%$ & $88.78 \%$ & $40.64 \%$ & $79.63 \%$ & $86.71 \%$ \\
\hline Goa & 0.00 & 0.00 & 0.00 & 0.01 & 0.02 & $0.00 \%$ & $0.00 \%$ & $0.00 \%$ & $0.45 \%$ & $1.38 \%$ \\
\hline Gujarat & 0.00 & 7.21 & 0.10 & 0.44 & 0.20 & $0.00 \%$ & $72.50 \%$ & $2.62 \%$ & $10.31 \%$ & $3.96 \%$ \\
\hline Haryana & 0.00 & 0.00 & 0.00 & 0.00 & 0.00 & $0.00 \%$ & $0.00 \%$ & $0.00 \%$ & $0.00 \%$ & $0.00 \%$ \\
\hline Himachal Pradesh & 0.01 & 22.40 & 0.00 & 8.74 & 1.26 & $0.04 \%$ & $92.47 \%$ & $0.00 \%$ & $80.05 \%$ & $38.46 \%$ \\
\hline Jharkhand & 0.00 & 45.94 & 6.42 & 19.85 & 10.20 & $0.00 \%$ & $96.61 \%$ & $68.52 \%$ & $92.76 \%$ & $82.71 \%$ \\
\hline Karnataka & 0.00 & 1.19 & 0.00 & 0.00 & 0.00 & $0.00 \%$ & $49.77 \%$ & $0.00 \%$ & $0.00 \%$ & $0.00 \%$ \\
\hline Kerala & 0.00 & 3.17 & 1.30 & 5.87 & 1.14 & $0.00 \%$ & $60.86 \%$ & $32.24 \%$ & $70.82 \%$ & $31.88 \%$ \\
\hline Madhya Pradesh & 0.00 & 0.00 & 0.00 & 0.00 & 0.00 & $0.00 \%$ & $0.00 \%$ & $0.00 \%$ & $0.00 \%$ & $0.00 \%$ \\
\hline Maharashtra & 0.00 & 3.75 & 0.13 & 0.19 & 0.16 & $0.00 \%$ & $74.52 \%$ & $7.71 \%$ & $13.83 \%$ & $10.34 \%$ \\
\hline Manipur & 0.19 & 12.23 & 0.00 & 0.65 & 0.08 & $0.11 \%$ & $88.89 \%$ & $0.00 \%$ & $12.42 \%$ & $4.92 \%$ \\
\hline
\end{tabular}




\begin{tabular}{|c|c|c|c|c|c|c|c|c|c|c|}
\hline Meghalaya & 0.07 & 89.42 & 0.00 & 73.30 & 0.89 & $0.53 \%$ & $97.10 \%$ & $0.00 \%$ & $96.52 \%$ & $43.38 \%$ \\
\hline Mizoram & 0.00 & 0.00 & 0.00 & 124.57 & 67.82 & $0.00 \%$ & $0.00 \%$ & $0.00 \%$ & $98.25 \%$ & $96.83 \%$ \\
\hline Nagaland & 0.20 & 254.76 & 20.96 & 893.60 & 333.56 & $0.01 \%$ & $97.47 \%$ & $76.26 \%$ & $99.36 \%$ & $97.03 \%$ \\
\hline Orissa & 0.00 & 22.13 & 0.30 & 1.60 & 0.49 & $0.01 \%$ & $93.40 \%$ & $11.14 \%$ & $54.71 \%$ & $23.14 \%$ \\
\hline Punjab & 0.00 & 20.60 & 1.53 & 3.01 & 1.78 & $0.00 \%$ & $89.21 \%$ & $26.85 \%$ & $56.17 \%$ & $36.70 \%$ \\
\hline Rajasthan & 0.00 & 25.51 & 2.94 & 43.01 & 4.60 & $0.00 \%$ & $92.92 \%$ & $45.98 \%$ & $93.33 \%$ & $66.63 \%$ \\
\hline Sikkim & 0.00 & 0.00 & 0.00 & 0.00 & 0.00 & $0.00 \%$ & $0.00 \%$ & $0.00 \%$ & $0.00 \%$ & $0.00 \%$ \\
\hline Tamil Nadu & 0.00 & 3.08 & 0.18 & 1.11 & 0.20 & $0.00 \%$ & $71.49 \%$ & $11.27 \%$ & $46.97 \%$ & $13.40 \%$ \\
\hline Telangana & 0.00 & 0.00 & 0.00 & 0.00 & 0.00 & $0.00 \%$ & $0.00 \%$ & $0.00 \%$ & $0.00 \%$ & $0.00 \%$ \\
\hline Tripura & 0.00 & 0.00 & 0.00 & 0.00 & 0.00 & $0.00 \%$ & $0.00 \%$ & $0.00 \%$ & $0.00 \%$ & $0.00 \%$ \\
\hline Uttar Pradesh & 0.00 & 0.00 & 0.00 & 0.00 & 0.00 & $0.00 \%$ & $0.00 \%$ & $0.00 \%$ & $0.00 \%$ & $0.03 \%$ \\
\hline Uttarakhand & 0.00 & 0.00 & 0.00 & 0.00 & 0.00 & $0.00 \%$ & $0.00 \%$ & $0.00 \%$ & $0.00 \%$ & $0.00 \%$ \\
\hline West Bengal & 0.00 & 13.94 & 0.74 & 2.54 & 0.66 & $0.01 \%$ & $87.88 \%$ & $21.43 \%$ & $55.00 \%$ & $21.45 \%$ \\
\hline $\begin{array}{l}\text { Andaman \& } \\
\text { Nicobar Is. }\end{array}$ & 0.00 & 0.00 & 0.00 & 0.00 & 0.00 & $0.00 \%$ & $0.00 \%$ & $0.00 \%$ & $0.00 \%$ & $0.00 \%$ \\
\hline Chandigarh & 0.00 & 0.00 & 0.02 & 0.00 & 0.00 & $0.00 \%$ & $0.00 \%$ & $0.86 \%$ & $0.04 \%$ & $0.10 \%$ \\
\hline $\begin{array}{l}\text { Dadraagar } \\
\text { HaveliDaman\&Diu }\end{array}$ & 0.02 & 30.81 & 1.83 & 20.27 & 3.47 & $0.07 \%$ & $93.26 \%$ & $51.24 \%$ & $90.00 \%$ & $64.44 \%$ \\
\hline Delhi & 0.00 & 0.00 & 0.00 & 0.00 & 0.00 & $0.00 \%$ & $0.00 \%$ & $0.00 \%$ & $0.00 \%$ & $0.00 \%$ \\
\hline $\mathrm{J} \& \mathrm{~K}$ & 0.00 & 0.00 & 0.00 & 0.00 & 0.00 & $0.00 \%$ & $0.00 \%$ & $0.00 \%$ & $0.06 \%$ & $0.10 \%$ \\
\hline Lakshadwep & 0.00 & 0.00 & 0.00 & 0.00 & 0.00 & $0.00 \%$ & $0.00 \%$ & $0.00 \%$ & $0.00 \%$ & $0.00 \%$ \\
\hline Puducherry & 0.00 & 5.25 & 0.17 & 0.69 & 0.12 & $0.00 \%$ & $72.67 \%$ & $5.31 \%$ & $24.62 \%$ & $4.63 \%$ \\
\hline Total & 0.00 & 3.87 & 0.19 & 0.71 & 0.22 & $0.00 \%$ & $72.58 \%$ & $9.69 \%$ & $33.56 \%$ & $12.38 \%$ \\
\hline
\end{tabular}

Source: Author's Calculations based on the IRDA Annal Report 2019-20

\section{COMPARISON WITH TOTAL HEALTH POLICIES IN 2019-20}

GSHISs is now becoming the major form of Health Insurance in the country in terms of the Insured. But for the GSHISs, three fourth of the nation don't even know about the Health Insurance. The comparison with the total health insurance in the country, reveals that in the state of Nagaland, only GSHIS- form of Group Health policies are popular as health-insured under GSHISs are $97.47 \%$ of the total health insured in the state covered so, only by GSHISs in the year 2019-20. On an average, in the country $72.58 \%$ of the health-insured $\mathrm{s}$ are insured under GSHISs only in 2019-20. Meghalaya, Jharkhand, Orissa, Dadra \& Nagar Haveli and Daman \& Diu, Rajasthan, Himachal Pradesh, Orissa, Punjab, Manipur, Chhattisgarh, West Bengal, Bihar, Maharashtra, Puducherry, are the other states /Union Territories which are above this national average. In the state of Tamil Nadu $71.49 \%$ of the health insured persons are covered so in GSHISs in the year 2019-20.

Comparing the Gross Direct Premium collected under GSHISs, only $9.69 \%$ of the total health insurance premium is received by the insurance industry through GSHISs. In the state of Nagaland 76.29\% of the Gross Direct Premium are only from the GSHISs, revealing the fact that the health insurance sector is yet to penetrate the north East Frontier of the Country. In Jharkhand and Dadra \& Nagar Haveli and Daman \& Diu (UT) also more than half of the Gross
Direct Premium is sponsored by the Government(s). Rajasthan, Chhattisgarh, Kerala, Punjab, West Bengal, Tamil Nadu, Orissa are the other states which sponsor more amount of Health insurance Premium than the national average of $9.69 \%$ to the total health premium in the year 2019-20.

Comparing the number of claims paid under GSHISs to the total number of claims in the year 201920 , around one third of the total number of health insurance claims is paid by the insurance industry as GSHISs claims. Due to the less per capita health claim under GSHISs, $12.38 \%$ of the amount of claim is paid by the insurance industry as GSHISs claims in the year 2019-20 in India. As a leading state, in Nagaland, $99.36 \%$ of the total number of the health insurance claims paid (97.03\% of the amount of claims) are made under the GSHISs only, revealing the fact that the health insurance benefits the poor in the state, who might have been avoiding seeking the health care at all or might have met with OOP expenditure. In Mizoram also more than $90 \%$ of the number of health insurance claims as well as amount of total amount of health claims were under the GSHISs only.

Meghalaya, Rajasthan, Jharkhand and Dadra \& Nagar Haveli and Daman \& Diu are the other states /UTs in which more than $90 \%$ of the number of health insurance claims were under the GSHISs only. Himachal Pradesh, Chhattisgarh, Kerala, Punjab, West Bengal, Orissa, Assam and Tamil Nadu are the other states which had more number of claims being admitted 
in GSHISs comparing the national average of $33.56 \%$ to the total health claims in the year 2019-20.

Similarly, in addition to Nagaland

and

Mizoram, Chhattisgarh (86.71\%), Jharkhand

$(82.71 \%)$, Rajasthan (66.63\%), Dadra \& Nagar Haveli and Daman \& Diu (64.44\%), Meghalaya

(43.38\%), Himachal Pradesh (38.46\%), Punjab(36.70\%), Kerala(31.88\%), Orissa(23.14\%), West Bengal(21.45\%), Tamil Nadu(13.40\%), which had more amount of claims being admitted in GSHISs comparing the national average of $12.38 \%$ to the total health claims' amount in the year 2019-20.

\section{CONCLUSION}

In this paper only the supply side financial aspect from the view of the insurers is analysed, comparing the performance of different states. It reveals that In terms of amounts of claims paid, in terms of number of persons covered under GSHISs and In terms of premium paid for GSHISs, Maharashtra is in the first place, playing consistent performance in all these three grounds. Similarly, in terms of amounts of claims paid, in terms of number of persons covered under GSHISs and In terms of number of claims paid under GSHISs, Tamil Nadu is in the third place. The AB-PMJAY Annual Report 2020-21 also confirms this fact that the top performer in terms of the hospitalization per lakh of population is high in case of the states Kerala, Gujarat, Chhattisgarh, Goa and Tamil Nadu. Maharashtra though seems to be a super performer, when compared with the population relatively, with respect to the famous GSHIS, ABPMJAY, it is not even in first five places. The hilly states including the north eastern states are remaining under performers in all the area of comparisons.

Till the year 2019-20, Andhra Pradesh, Arunachal Pradesh, Haryana, Madhya Pradesh, Sikkim, Telangana, Tripura, Uttarakhand, Andaman \& Nicobar Island, Delhi and Lakshadweep did not join the GSHIS mainstream and no single rupee of claim was made in these States and UTs. Only this year AB-PMJAY is made pan-Indian presence as a few states were reluctant in joining to the one-nation one-insurance slogan till last year. Unless all the states implement the GSHISs particularly the AB-PMJAY effectively, it is difficult to attain the Universal Health Coverage Goal of the country. It is not just the numbers that count but of course the quality and timely care to the needy poor also. Similarly the concept of cashless hospitalization should not be yet another cliché and if the people feel that they are to pay around half of the hospitalization money, they may keep avoiding approaching hospitals again which in due course may nullify the very purpose of GSHISs.
Acknowledgement: This paper is part of the research work of the major research project sponsored by ICSSR to the author.

\section{REFERENCES}

1. IRDA Annual Reports available at www.irda.gov.in

2. AB-PMJAY Annual Report available at https://pmjay.gov.in/

3. Pugazhenthi.V and Sunitha.C, "The Government Sponsored Health Insurance Schemes for the Gross Domestic Healthiness", Journal of Health Management, Volume 17 Number 4, pp-438-445 (October-December, 2015) available at http://intljhm.sagepub.com DOI:10.1177/0972063415606276

4. Pugazhenthi.V and Sunitha.C, "Role of Government Sponsored Health Insurance Schemes in Public Health Management In Tamil Nadu", Indian Journal of Management, volume7 Issue 12,Dec 2014,pp.7-21

5. Pugazhenthi.V and Sunitha.C "A Study on Impact of Health Insurance Growth on Sectoral Changes in the Indian Non Life Insurance Industry", International journal of Research and Development in Technology and Management -Kailash Volume: 21,Issue3,August 2014, pp.36-45

6. "Pugazhenthi.V and Sunitha.C An Analysis of Investments of Indian Insurers in the Financial Year 2012-13", Best:International Journal of Humanities, Arts, Medicine and Sciences, Vol 2, Issue 8, August 2014 , pp.45-54

7. Pugazhenthi.V and Sunitha.C, "Changing Market Structure in Indian Insurance Industry-As revealed by Concentration ratio and Herfindahl-Hirschman index" Intercontinental Journal of Finance Research Review, Volume 2 ,Issue 7, July 2014, pp.64-80.

8. Pugazhenthi.V and Sunitha.C "Analysis of the Performance and Growth of Indian Standalone Health Insurers", Economic Challenger, Issue 64, July-Sep.2014.

9. Pugazhenthi.V and Sunitha.C "Analysis of Satisfaction of beneficiaries from the Health Insurance Schemes of Government of Tamil Nadu", EPRA International Journal of Economic and Business Review-Online, Vol-2, Issue-6, June2014, pp. 8-14

10. Pugazhenthi.V and Sunitha.C "Health Insurance for Healthy India", International Journal of Environmental Economics ,Commerce And Management Studies, April 2014, pp.157-163

11. Pugazhenthi.V and Sunitha.C "An Analysis of Awareness About the features of Chief Minister's Comprehensive Health Insurance Schemes of Government of Tamil Nadu”, Inter- Continental Marketing Research Review, Volume 2 ,Issue 4, April 2014, pp.1-17

12. "Pugazhenthi.V and Sunitha.C, ,Indian Health Insurance claims- a macro Level Analysis", Research Explorer, Volume 2, Issue 3, Feb 2013, pp1266-1269. 
13. Pugazhenthi.V and Sunitha.C "A Macro level study on Indian Health Insurance Claims" SELP Journal of Social science, Vol. IV ,Part II, , issue 15 pp. 119-124, April 2013

14. Pugazhenthi.V and Sunitha.C A study on significance of Public Expenditure on Health and family welfare, SELP Journal of Social Science, Vol. IV, Part I, April 2013, issue 15, pp134-139

15. Pugazhenthi.V and Sunitha.C "Catastrophe insurance for Gross National Happiness" International Journal of Applied Management and Research Vol:3, Issue 1 June 2011, pp 45-52,

16. Pugazhenthi.V and Sunitha.C An Analysis of claims of Indian Health Insurance industry during 20092010”, International Journal of Applied Management and Research Vol:2 , Dec 2010pp642-646

17. Pugazhenthi.V and Sunitha.C A Study on awareness of Health Insurance among life insured women", International Journal of Applied Management and Research Vol:2, Dec 2010-pp 590-593

18. Pugazhenthi.V and Sunitha.C , CRM in Insurance Industry, "SMART Journal of Business Management Studies-Vol2, No.1,2006, 